\title{
PECULIARITIES OF YOUTH LIFESTYLE FORMING UNDER THE SOCIAL MEDIA INFLUENCE
}

\author{
Sofiia Prudyvus ${ }^{1}$ \\ Lviv Polytechnic National University, Lviv, Ukraine \\ ${ }^{1}$ Student of bachelor program "Sociology", of Department of Sociology and Social Work
}

Olha Herus, scientific supervisor, Ph.D., assistant of the Sociology and Social Work Department of Lviv Polytechnic National University

Background: In today's dynamic world, changes are occuring in all spheres of life, and perhaps the biggest shifts are happening in the sphere of communication. Thus, every year the usual print media, TV and radio are being replaced with social media. One of the advantages of social media is that it is more accessible. You can read the news after it was posted, rather than waiting for scheduled time of news on television. Thanks to social media, the amount of information in the world has increased, allowing people to always being "at the center of events".

Purpose: basing on analysis to determine the role of social media in shaping the lifestyle of young people.

Methods: The author uses analysis methods to determine the current state of social media influence problem and the method of comparison of theoretical and empirical studies of the social media impact on youth lifestyle forming.

Results: According to the analyzed researches we can speak about the fact that today social networks are shaping the world other than the real one, the world where it is easier to be someone you want to be, and where it is more easily to behave in a different way than in a real life.

Conclusion: Ont the one hand all Internet resources greatly simplifies life, provides the opportunities for self-education and additional earnings and self-realization. But on the other, there are a lot of threats and you need to keep in mind the balance of the virtual and the real. In both cases the Internet forms a certain lifestyle that manifests itself in adapting to the new Internet innovations of modern society.

Keywords: lifestyle, lifestyle forming, social media, social networks, Internet, .

У сучасному глобалізованому світі соціальні медіа є тим інструментом, який надає можливість активно взаємодіяти з навколишнім середовищем, дає можливість обирати те, що до душі людині, таким чином формуючи ії вподобання. Завдяки соціальним медіа, можна вільно комунікувати та співпрацювати з людьми, ділитися інформацією та брати участь у різного роду соціальних активностях, таких як флешмоби, підписувати різного роду петиції, та асоціювати себе із різними типами соціальних спільнот.

Соціальні медіа включають в себе велику кількість поєднання сервісів, що існують в мережі інтернет, наприклад, блоги; сайти, зроблені у вигляді статей, поміток або цікавих фактів; фотота відеосервіси, де користувачі мають можливість ділитися різного роду фотографіями та відео матеріалами (до прикладу YouTube, Instagram); подкасти, як новий спосіб поширення аудіота відеоконтенту. Одним із різновидів соціальних медіа $є$ соціальні мережі. Однією із важливих складових соціальних медіа є соціальні мережі. Вони виступають свого роду майданчиком, платформою для того, аби люди могли взаємодіяти один з одним без жодних проблем, могли організовувати різноманітні спільноти, групи та чати, відповідно до різного роду діяльності людини, різновиду інтересів, місця проживання, навчання, роботи або будьякої іншої ознаки. Соціальні мережі на сьогодні займають чільні місця у проведені дозвілля, що може характеризувати їх як заміну традиційному спілкуванню. Основними споживачами даної платформи $є$ молодь, адже вона $є$ тим елементом суспільства, який більше за всіх зазнає впливу соціальних медіа, оскільки є найактивнішим ii користувачем, а відтак носієм усіх тенденцій, що поширюються за допомогою соціальних медіа. 
У сучасному суспільстві проблема дослідження особливостей процесу соціалізації молоді через вплив соціальних мереж має чималий науковий інтерес. Проблематику соціальної взаємодії в мережі Інтернет висвітлено в дослідженнях зарубіжних соціологів: Н. Бейма, П. Коллока, С. Кайзлера, Г. Рейнгольда, Л. Спрелла, С. Херрінга та ін. Поняття "мережа" досліджували такі науковці, як Ф. Гваттарі, М. Грановеттер, М. Кастельс, Б. Латур, Н. Луман, Б. Уеллман та ін. Соціальні мережі розглядали такі зарубіжні вчені, як: Д. Барнс, Ф. Капра, Р. Коллінз, Я. Морено, А. Радклиф-Браун, Р. Хойслінг та ін. Проблема дослідження соціальних мереж також відображена в працях А. Архіпова, К. Бердник, С. Бондаренко, Г. Градосельского, Б. Докторова, А. Драмашко, Е. Князєвої, О. Лещенко, В. Лісічкіна, М. Моісеєва, В. Нестерова, Г. Почепцова, Б. Сазонова, В. Сілаєвої, А. Скуратова, В. Тищенко, Л. Шелепіна, О. Яніцького. У роботах А. Войськунського, М. Дрепи, Л. Бабаніна, Г. Солдатової, Е. Бєлінської досліджувалися психологічні, соціальні і соціально-психологічні причини інтернет-залежності та яку роль соціальні мережі відіграють у житті молоді.

Як зазначає дослідниця Л. Й. Гуменюк, грунтуючись на даних дослідження, проведеного у лютому-квітні 2011 року, глобальна мережа інтернет суттєво впливає на життя сучасної молоді (Гуменюк, 2013). У ході дослідження було опитано 800 студентів вищих навчальних закладів м. Львова. Предметом дослідження були соціальні мережі, як чинник соціалізації молоді, а мета дослідження полягала у визначенні ступеня впливу соціальних мереж на процес становлення особистості та можливостей виникнення узалежнення (Гуменюк, Жидецький, 2011). Авторами дослідження було визначено, що у вільний час більше як третина молоді проводиться своє дозвілля в мережі інтернет, а у відповідь на запитання «3 якою метою ви відвідуєте інтернет?», 63\% зазначили що відвідують інтернет, щоб переглянути фільми і послухати музику 71\%. Дане дослідження дало можливість визначити, що 74\% мають достатньо високу зацікавленість щодо користування соціальними мережами та їх інтегрованість в даний ресурс, 34\% молоді проводять в соціальних мережах- «1-2 години», 5\% відповіли «більше 6 годин в день». Щодо можливостей, які надають соціальні мережі, то, на думку, респондентів першочерговою є допомога у вирішенні питань, які в реальному житті вирішити важко або неможливо, а саме: «відносини 3 людьми», зокрема 3 представниками протилежної статі (32\%), в «дружбі» (50\%), «створення сім’ї» (62\%), «знання» (34\%). За даними дослідження особливо цінується у віртуальній реальності «чесність» (32\%), «незалежність і свобода» (37\%), «відсутність або обмеженість в реальному світі» (16\%). Студенти зазначали що у «віртуальному світі їм значно простіше сформулювати свої думки, «у соціальних мережах спокійніше спілкуватися» $(24 \%)$, «у віртуальному світі значно простіше, ніж в реальному житті» (28\%), «можна бути самим собою» (32\%) та інше. Отже, соціальні мережі для молоді є важливим чинником у формуванні їх дружніх відносин, місцем, де можна провести свій вільний час: послухати музику або подивитися фільми або почерпнути нові знання. Зокрема, користуючись соціальними мережами молоді значно простіше проявляти свої особисті якості. В свою чергу спостерігається, що користуванню соціальними мережами «щодня» - віддали перевагу $72 \%$ опитаних, що говорить про важливість соціальних мереж у житті молоді. Дана важливість від соціальних мереж може вести за собою таку поведінку, як залежну. Залежність може проявлятися в очікуванні нового посту людей за якими ти слідкуєш, в нових знайомствах, розвального вмісту соціальних мереж або ж в просуванні власної сторінки. Така поведінка може вести за собою зміну стилю життя молоді, адже відбувається заміна реальному світу віртуальним.

Також проводилися дослідження для визначення медіа-вподобань компанією GfK шляхом персональних інтерв'ю 2016-2017 року що проводилося у дві хвилі, де було опитано 15103 респонденти 320 січня по 5 березня 2017 року у восьми областях Півдня та Сходу (Соціологічна компанія Gfk, 2017). На території півдня та сходу України, де половина опитаних у 2017 році заявили, що користуються Інтернетом кожен день або майже кожен день (51\%), ще 9\% користувалися ним хоча б раз на тиждень. $38 \%$ опитаних сказали, що вони взагалі не користуються інтернетом. Основна діяльність людей в інтернеті - це ведення власних сторінок у соціальних мережах, комунікація між друзями, перегляд розважального 
контенту, спілкування в скайп-режимі, перегляд фільмів та ін. Респонденти, які зазначали, що взагалі не користуються інтернетом зазначали «в мене немає доступу до комп’ютера чи іншого пристрою для використання Інтернету». Згідно даних дослідження, 32016 до 2017, збільшилися частки опитаних, які мають сторінки в таких соціальних медіа як ВКонтакте (з 37 до 39\%), Facebook (з 13 до 19\%) та Instagram (зростання вдвічі - з 4 до 8\%). А, з іншого боку серед користувачів соціальних мереж, за рік зросли частки регулярних користувачів таких соціальних мереж як Facebook (з 48 до 54\%), Instagram (з 54 до 62\%) та Twitter (з 36 до 39\%).

Проведене дослідження дає можливість констатувати той факт, що в період з 2016 до 2017 року, соціальні медіа спрямовано входять в життя людей, що в свою чергу приймається людьми. Люди все більше стають зацікавлені у віртуальному просторі. Дана динаміка розвитку соціальних мереж може впливати на збільшення користувачів в них, на більше зацікавлення розвитку вже власних інтернет сторінок та збільшення проведення там значної частини свого часу. Такий розвиток соціальних мереж та зацікавлення в них людьми, свідчить про те, що українське суспільство на стадії розвитку новітніх технологій.

У березні 2019 року компанія Research \& Branding Group спільно з Агентством кризових комунікацій «НІ» провела другу хвилю дослідження, присвяченого користувачам соцмереж в Україні. Опитування проводилося в період з 18 по 27 березня 2019 року. Опитано 2001 респондента у віці від 18 років і старше. Вибірка репрезентує населення України за статтю, віком, типом населеного пункту та регіоном проживання (за винятком непідконтрольних територій Донецької і Луганської областей, АР Крим, та м.Севастополь). (Рейтинг популярності соціальних мереж в Україні , 2019). Як зазначають соціологи, за період з травня 2018 року до - березня 2019 року в Україні помітно збільшилося число таких користувачів соцмереж, як Facebook (до 50\%), YouTube (30\%), Instagram (27\%) і суттєво зменшилася кількість таких користувачів соцмереж, як Одноклассники (6\%) до і ВКонтакте (10\%). Зокрема таку тенденцію можна поянити тим, що в Україні з 28 квітня 2017 року заблоковані такі соціальні мережі як Вконтакті та Однокласники, тому люди шукають альтернативу цим мережам. Таким чином зростає частка користування такими соціальними мережами як Facebook, YouTube, Instagram. Ці соціальні мережі містять найбільшу концентрацію розвального та пізнавального вмісту, що і приваблює людей (Практика пользования соцсетями в Украине, 2019).

Молодь активно користується соціальними мережами та усіма їхніми можливостями. Дані проаналізованих досліджень свідчать про те, що активне користування соціальними мережами впливає на молодь, а саме іiі вподобання та вибір, які формуються зокрема під впливом соціальних мереж. Відтак, частка користування молоддю соціальними мережами збільшується 3 кожним роком.

Висновки: За даними проаналізованих досліджень можемо говорити про той факт, що сьогодні соціальні мережі є світом, відмінним від реального, світом, у якому менше проблем, в якому легше бути собою, в якому спокійніше і ніхто не осудить. Соціальні мережі провокують певні зміни стилю життя, наприклад, коли індивід спочатку проводив активний спосіб життя, а потім перейшов на віртуальний, що говорить про те, як соціальні мережі можуть втягувати в своє середовище для існування. Проте, можу погодитися, що світова павутина значно спрощує нам життя, дає можливості для самоосвіти та додаткового заробітку, існує можливість самореалізації. Проте необхідно пам'ятати про баланс віртуального та реального. На сьогодні інтернет-адикція молоді наближена з залежністю молоді та формує певний стиль життя, який проявляється в пристосуванні себе до нових інтернет-новацій сучасного суспільства.

\section{References}

Humeniuk L. Y. (2013) Internet-adyktsiia molodi u sotsialnomu vymiri. Visnyk ONU im. I.I. Mechnykova.Sotsiolohiia i politychni nauky (P. 9)

Humeniuk L.I., Zhydetskyi Yu.Ts. (2011) Pedahohichni umovy efektyvnoho vykorystannia mediaresursiv u navchalno-vykhovnomu protsesi vyshchykh navchanlykh zakladiv Ministerstva 
vnutrishnikh sprav Ukrainy. «Informatsiini tekhnolohii i zasoby navchannia»:elektronne naukove fakhove vydannia, tom 24, №4. URL: http://www.journals.iitts/gov.ua

Problemy suchasnoi psykholohii: Zbirnyk naukovykh prats Kamianets-Podilskoho natsionalnoho universytetu imeni Ivana Ohiienka, Instytutu psykholohii imeni H.S. Kostiuka NAPN Ukrainy (2014). Za red. S.D. Maksymenka, L.A. Onufriievoi. Vyp. 24. (P. 339 - 348). KamianetsPodilskyi: Aksioma.

Sotsiolohichna kompaniia GFK. Analitychnyi zvit pro rezultaty sotsiolohichnoho opytuvannia meshkantsiv pivdennykh i skhidnykh oblastei Ukrainy, 2016-2017 (P. 4-15) URL: https://imi.org.ua/wp-content/uploads/2017/07/IMI-sociology-final-report.pdf.

Reitynh populiarnosti sotsialnyh merezh v Ukraini (2019). URL: https://www.rbc.ua/ukr/news/sostavlen-reyting-populyarnosti-sotsialnyh-1555070035.html

Praktyka polzovanyia sotssetiamy v Ukrayne (2019). URL: http://rb.com.ua/blog/doverie-ukraincevsocsetjam-i-jekspertam/.

\section{Список використаних джерел:}

Гуменюк Л. Й. (2013) Інтернет-адикція молоді у соціальному вимірі. Вісник ОНУ ім. I.I. Мечникова. Соціологія і політичні науки (С. 9)

Гуменюк Л.Й., Жидецький Ю.Ц. (2011) Педагогічні умови ефективного використання медіаресурсів у навчально-виховному процесі вищих навчаньлих закладів Міністерства внутрішніх справ України. «Інформаційні технології $i$ засоби навчання»:електронне наукове фахове видання, том 24, №4. URL: http://www.journals.iitts/gov.ua

Проблеми сучасної психології: Збірник наукових праць Кам'янець-Подільського національного університету імені Івана Огієнка, Інституту психології імені Г.С. Костюка НАПН України (2014). За ред. С.Д. Максименка, Л.А. Онуфрієвої. Вип. 24. (с.339 - 348). Кам'янець-Подільський: Аксіома.

Соціологічна компанія GFK. Аналітичний звіт про результати соціологічного опитування мешканців південних і східних областей України, 2016-2017 (C. 4-15). URL: https://imi.org.ua/wp-content/uploads/2017/07/IMI-sociology-final-report.pdf.

Рейтинг популярності соціальних мереж в Україні (2019). URL: https://www.rbc.ua/ukr/news/sostavlen-reyting-populyarnosti-sotsialnyh-1555070035.html

Практика пользования соцсетями в Украине (2019). URL: http://rb.com.ua/blog/doverieukraincev-socsetjam-i-jekspertam/.

\section{Contact information:}

Sofiia Prudyvus

Sofiia.Prudyvus.SO.2017@1pnu.ua 